\title{
Blood pressure and serum cholesterol among male Ethiopian immigrants compared to other Israelis
}

\author{
Manfred S Green, Tali Etzion, Eliezer Jucha
}

\begin{abstract}
Study objective-The aim was to determine the effect of migration from a non-industrialised to an industrialised society on age related changes in blood pressure and serum cholesterol.

Design-The study was a comparison of major risk factors for cardiovascular disease in cross sectional surveys in two groups: Ethiopian immigrants and Israeli industrial employees.
\end{abstract}

Setting-Ethiopian immigrants were examined at Army induction centres in Israel; industrial employees were examined in the course of a national Israeli study on occupational risk factors for cardiovascular disease.

Participants-Participants were a sample of 387 male Ethiopians, aged 20-49 years, examined in 1987, who had immigrated to Israel three to four years previously, and a sample of 2747 male Israeli industrial employees in the same age group examined in 1985-7.

Measurements and main resultsAmong the Ethiopians there were no cases of overweight (Quetelet's index above $\mathbf{2 \cdot 8}$ ) and only $6.7 \%$ were smokers, as compared with $20 \cdot 7 \%$ overweight and $47 \cdot 1 \%$ smokers among the other Israelis ( $p<0.001$ for both variables). There were no significant differences in the prevalence of hypertension $(11.6 \%$ and $13.0 \%$ for Ethiopians and other Israelis respectively). Hypercholesterolaemia ( $>5.2 \mathrm{mmol} / \mathrm{litre}$, $200 \mathrm{mg} / \mathrm{dl}$ ) was much more prevalent among the other Israelis $(42.0 \% \quad v \quad 9.6 \%$, p < 0.001 ). Blood pressures were similar and increased with age in both groups. However, in contrast to the other Israelis, average serum cholesterol among the Ethiopians was low and increased minimally with age. After regression adjustment for age and body mass index, blood pressures were higher among the Ethiopians, whereas serum cholesterol remained considerably higher among the other Israelis. Serum cholesterol was correlated with blood pressure in both groups.

Conclusions-Since Ethiopian immigrants have been found to have uniformly low blood pressures on arrival in Israel, these findings suggest that there is an age dependent effect on blood pressure resulting from migration which is not reflected in the serum cholesterol values.
In industrialised populations, age and body mass consistently emerge as strong correlates of blood pressure and blood cholesterol, ${ }^{1-3}$ with these factors themselves being correlated with one another. ${ }^{2-4}$ These observations have been made in populations where the prevalence of risk factors for cardiovascular disease is high and a considerable proportion of the population have multiple risk factors. ${ }^{5}$ In non-industrialised societies, age is a weaker correlate of blood pressure and changes in this pattern following migration to industrialised societies have been demonstrated in several studies. ${ }^{6-8}$

The recent immigration of Ethiopians to Israel provided the opportunity to evaluate the association of age and body mass with blood pressure and serum cholesterol in subjects from a non-industrialised country, examined several years after their immigration to Israel.

\section{Methods}

A sample of 387 male immigrants from Ethiopia being examined at army induction centres in Israel in 1987 were included in the study. A single investigator was assigned to interview the subjects and take blood pressure and anthropometric measurements. The interview data included date of birth, years since immigration, and smoking habits. The physical examination included height, weight, and blood pressure measurements. The blood pressure was measured twice on the right arm using a standard sphygmomanometer (Baumanometer) with the subject sitting and following a rest of three to four minutes. The systolic blood pressure corresponded to the first Korotkoff sound and the diastolic blood pressure to the fifth Korotkoff sound (or the fourth where the sounds did not disappear). The blood pressures used in the statistical analyses are the average of the two readings. Relative weight was defined by Quetelet's index (weight in grams/[height in $\mathrm{cm}^{2}$ ). Non-fasting venous blood samples were taken and the sera were stored at $-20^{\circ} \mathrm{C}$ until analysed. For technical reasons, serum cholesterol was only determined in a random subsample of 154 subjects.

For the purpose of comparison, we used data on male participants from the CORDIS project, an epidemiological study of occupational risk factors for cardiovascular disease in Israel. In this study, about 6000 personnel in 21 factories in Israel were examined during 1985-7, and data were available on 2747 males between the ages of 20 and 49 years. This is the best dataset on cardiovascular risk factors available on the Israeli population during the period that the Ethiopian sample was 
examined. Since this is an occupational cohort, some aspects of the healthy worker effect may be present. However, although the cohort represents only a working population, only those under 50 years of age are included in the analyses and the healthy worker effect resulting from attrition of workers due to disease should be minimal. Thus using this as the comparison group for the Ethiopian sample appears to be reasonable.

While it was unavoidable that different examiners were used in the two studies, this could produce bias. However, in both studies, the

Table I Prevalence $(\%)$ of selected risk factors for ischaemic heart disease in a sample of male Ethiopian immigrants to Israel compared with Israelis examined in the CORDIS project

\begin{tabular}{|c|c|c|c|c|}
\hline \multirow[b]{2}{*}{ Characteristic $^{\mathrm{a}}$} & \multicolumn{2}{|l|}{$20-34$ years } & \multicolumn{2}{|l|}{$35-49$ years } \\
\hline & $\begin{array}{l}\text { Ethiopian } \\
\text { immigrants }\end{array}$ & $\begin{array}{l}\text { Other } \\
\text { Israelis }\end{array}$ & $\begin{array}{l}\text { Ethiopian } \\
\text { immigrants }\end{array}$ & $\begin{array}{l}\text { Other } \\
\text { Israelis }\end{array}$ \\
\hline $\begin{array}{l}\mathbf{n} \\
\text { Definite hypertension } \\
(S B P \geqslant 160 \text { or } D B P \geqslant 95)\end{array}$ & $\begin{array}{l}269 \\
2 \cdot 2\end{array}$ & $\begin{array}{c}1100 \\
2 \cdot 0\end{array}$ & $\begin{array}{c}118 \\
1.7\end{array}$ & $\begin{array}{c}1647 \\
7 \cdot 4 \dagger\end{array}$ \\
\hline $\begin{array}{l}\text { Definite or borderline } \\
\text { hypertension } \\
(S B P \geqslant 140 \text { or } D B P \geqslant 90)\end{array}$ & $9 \cdot 3$ & $10 \cdot 0$ & $16 \cdot 9$ & $15 \cdot 0$ \\
\hline $\begin{array}{l}\text { Serum cholesterol } \\
\geqslant 6.5 \mathrm{mmol} / \text { litre }(250 \mathrm{mg} / \mathrm{dl})\end{array}$ & $\begin{array}{l}2 \cdot 4 \\
(\mathrm{n}=84)\end{array}$ & 3.9 & $\begin{array}{l}0.0 \\
(n=70)\end{array}$ & $13 \cdot 6 \ddagger$ \\
\hline $\begin{array}{l}\text { Serum cholesterol } \\
\geqslant 5.2 \mathrm{mmol} / \text { litre }(200 \mathrm{mg} / \mathrm{dl})\end{array}$ & $9 \cdot 5$ & $25 \cdot 00 \ddagger$ & $10 \cdot 0$ & $53 \cdot 3 \ddagger$ \\
\hline $\begin{array}{l}\text { Cigarette smoking } \\
\text { Obesity (Quetelet index } \geqslant 2 \cdot 8 \text { ) }\end{array}$ & $\begin{array}{l}7 \cdot 1 \\
0 \cdot 0\end{array}$ & $\begin{array}{l}48 \cdot 8 \ddagger \\
14 \cdot 5 \ddagger\end{array}$ & $\begin{array}{l}5 \cdot 9 \\
0 \cdot 0\end{array}$ & $\begin{array}{l}46 \cdot 4 \ddagger \\
24 \cdot 8 \ddagger\end{array}$ \\
\hline
\end{tabular}

a Tests for difference between percentages between Ethiopian immigrants and other Israelis based on the approximation to the normal distribution

$\mathrm{SBP}=$ Systolic blood pressure; $\mathrm{DBP}=$ diastolic blood pressure

$\dagger \mathrm{p}<0.01, \pm \mathrm{p}<0.001 v$ Ethiopian immigrants examiner of the Ethiopian group and the three examiners in the CORDIS study were trained by the same investigator (the senior author of this paper) and this should reduce some of the bias. The schedule of blood pressure measurements was slightly different in each study. For the Ethiopians, two sitting blood pressure measurements were taken, whereas in the occupational cohort, three blood pressures, one supine followed by two sitting, were taken. To minimise intraindividual variation, the average of the two blood pressures was used for the Ethiopians. The option for the other group was either to use the average of the first two measurements, or the average of the two sitting measurements. Since blood pressure tends to be lower with each successive measurement, particularly following the first measurement when the subject has not yet experienced the feel of the instrument, use of the second and third measurements in the CORDIS group might significantly underestimate the blood pressures compared with the Ethiopians. For this reason the average of the first and second measurements was used for both groups in these analyses.

Serum cholesterol was measured on bloods drawn after an 8-10 h fast. Since serum cholesterol levels are not significantly affected by immediate dietary intake, ${ }^{9}$ the comparison between the two groups should be unaffected by

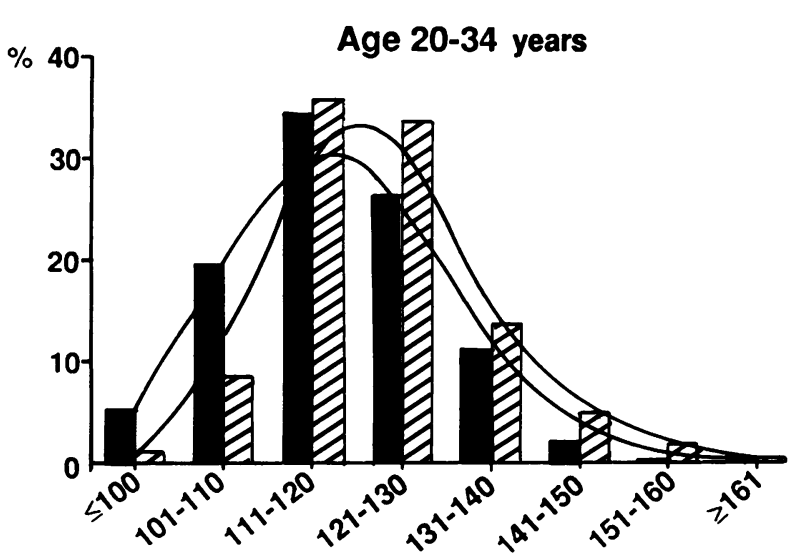

Systolic blood pressure $(\mathrm{mm} \mathrm{Hg})$

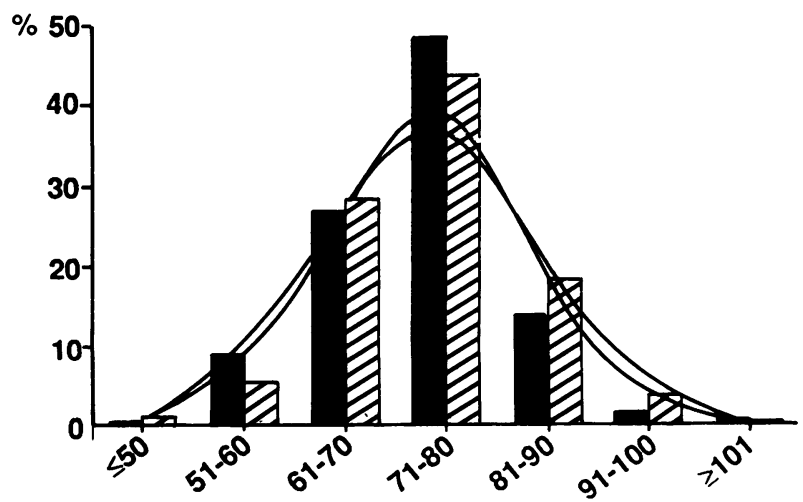

Diastolic blood pressure $(\mathrm{mm} \mathrm{Hg})$
Age $35-49$ years
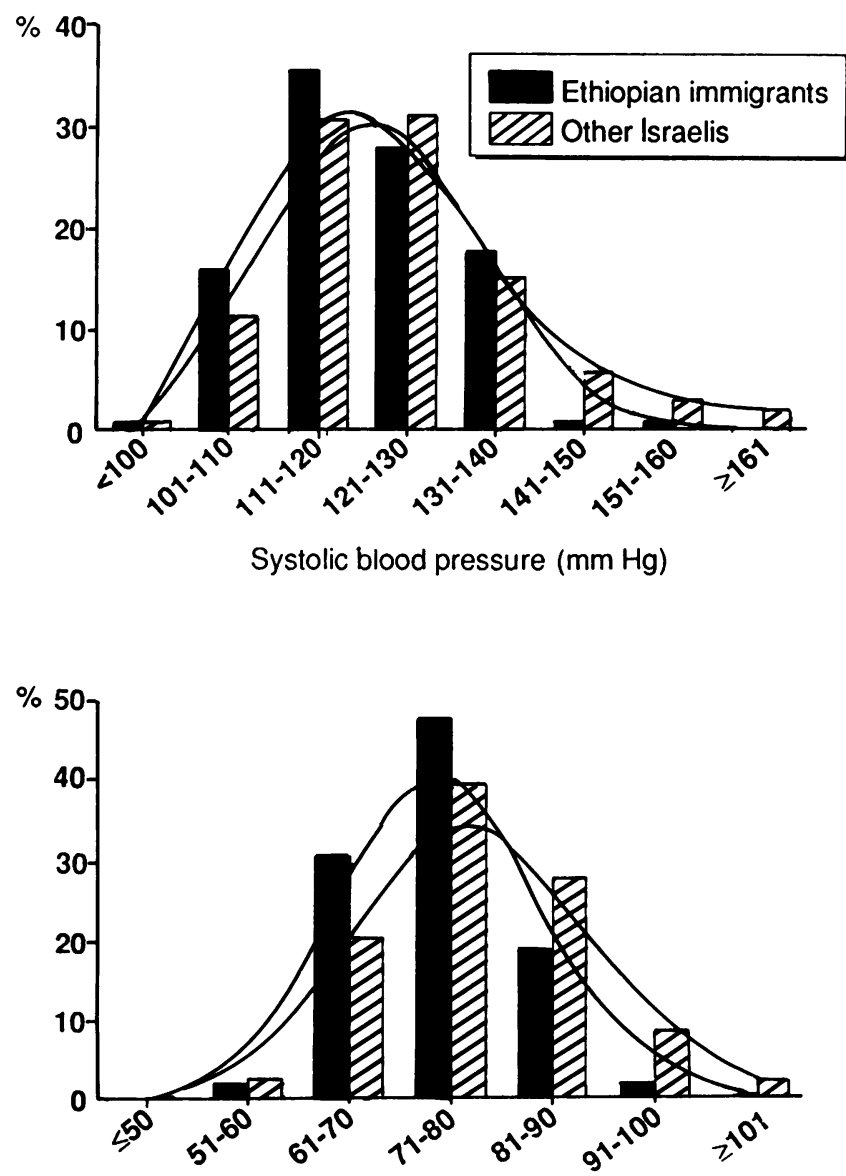

Diastolic blood pressure $(\mathrm{mm} \mathrm{Hg})$

Figure 1 Frequency distributions of systolic and diastolic blood pressure, by age group, for Ethiopian immigrants in Israel compared with other Israelis examined in the CORDIS project. 
the different conditions of fasting prior to drawing blood.

The normal approximation test was used to compare differences between percentages. The normal test for differences between means was used to compare the continuous variables. Multiple linear regression was used to evaluate possible associations between different risk factors while controlling for possible confounding variables. In the text, results were regarded as significant for $\mathrm{p}$ values less than 0.05 .

\section{Results}

The prevalence of selected risk factors among the Ethiopians as compared with the other Israelis in the age groups $20-34$ and 35-49 years is shown in table I. The prevalence of definite hypertension was similar for Ethiopians and other Israelis in the younger age group whereas between 35 and 49 years it was significantly higher among other Israelis. For combined definite and borderline hypertension, no significant differences were observed between the two groups. The prevalence of hypercholesterolaemia (serum cholesterol $\geqslant 6.5 \mathrm{mmol} /$ litre, $250 \mathrm{mg} / \mathrm{dl}$ ) was similar in the younger age group but much higher for other Israelis in the older group. For serum cholesterol $\geqslant 5.2 \mathrm{mmol} /$ litre $(200 \mathrm{mg} / \mathrm{dl})$, the prevalence was much higher for other Israelis in both age groups. Smoking rates were much lower among Ethiopians. Overweight as defined by Quetelet index $\geqslant 2.8$ was absent among Ethiopians, whereas it was $14.5 \%$ and $24.8 \%$ respectively in the two age groups among other Israelis.

The frequency distributions of blood pressure, cholesterol, and Quetelet index by age group are shown for the Ethiopians and other Israelis in figs 1 and 2. While the distributions are similar for blood pressure, marked differences are observed for Quetelet index and serum cholesterol. The other Israelis show a marked shift to the right relative to the Ethiopians, particularly for Quetelet index and particularly in the older age group. The mean systolic and diastolic blood pressures, Quetelet index, and serum cholesterol by age were compared between the Ethiopians and the Israelis examined in the CORDIS project (fig 3). The Ethiopians had lower systolic blood pressure than the other Israelis, although this was statistically significant only between the ages of 20 and 29 years. Differences in diastolic blood pressure were not statistically significant at any age. For cholesterol the differences were striking, with the Ethiopians having lower levels mainly from age 35 years $(p<0.001)$ and showing virtually no change with age, in contrast to the other Israelis who showed a consistent age related increase. The Ethiopians had much lower Quetelet values than the other Israelis $(p<0.001$ at all ages), with very little change with age in contrast to the increase observed among other Israelis.
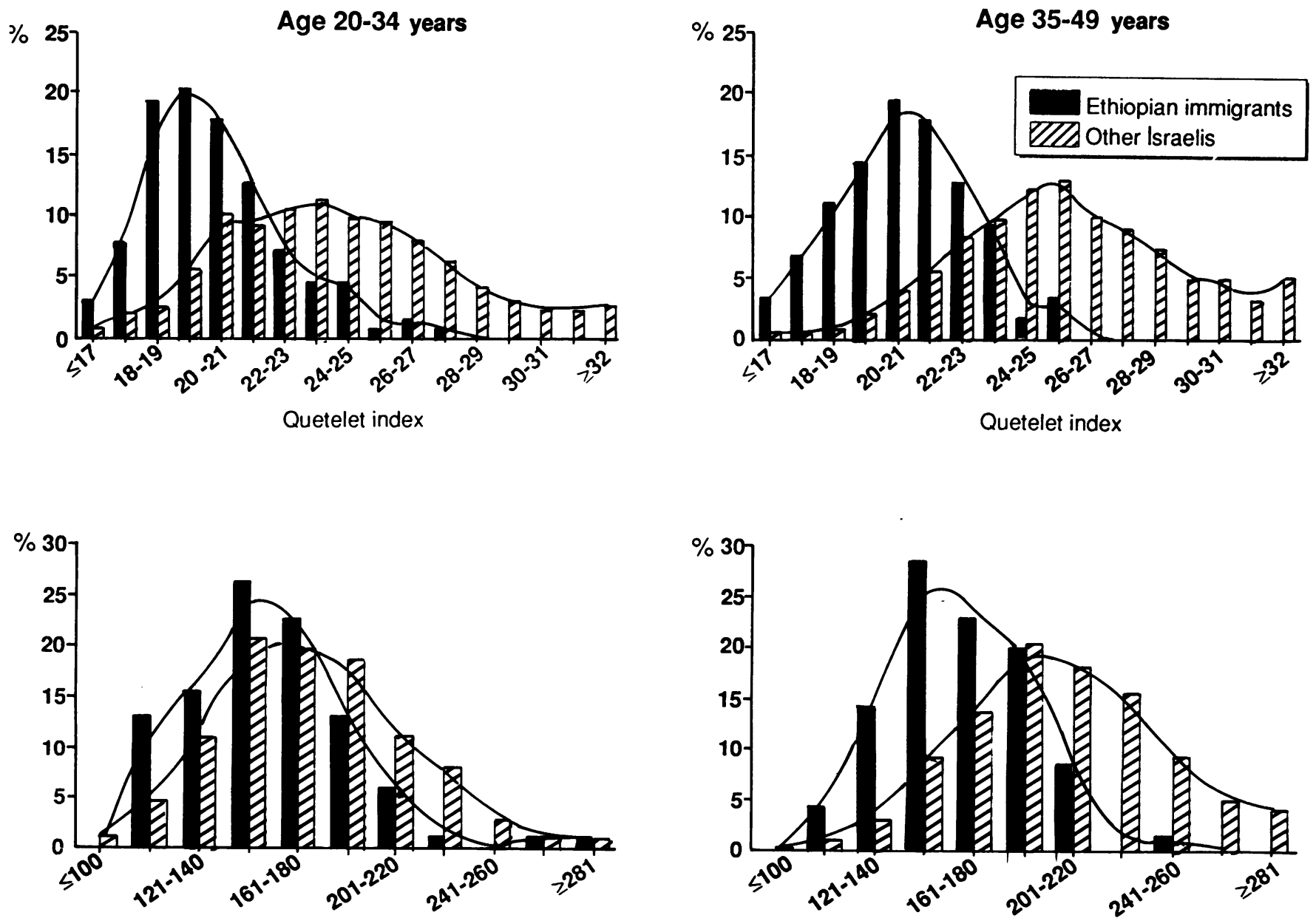

Total cholesterol (mg/dl)

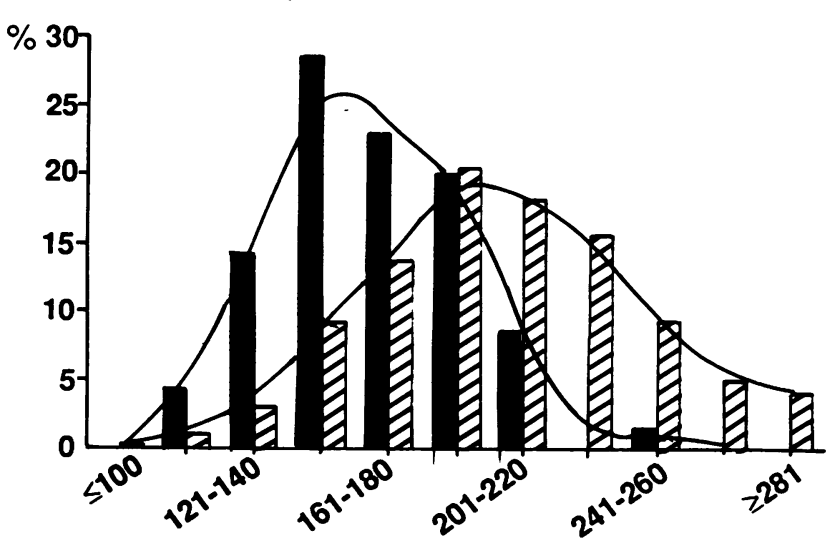

Total cholesterol (mg/dl)

Figure 2 Frequency distributions of Quetelet index and serum cholesterol by age group for Ethiopian immigrants in Israel compared with other Israelis examined in the CORDIS project. 
Regression lines of blood pressure and cholesterol by age while controlling for Quetelet index are shown in fig 4. After adjustment, Ethiopians had higher blood pressures and similar age related changes. There was a clear increase in cholesterol with age for the other Israelis compared with a minimal change for the Ethiopians. It should be noted that the poor overlap in the frequency distributions of Quetelet index for the two groups indicates that the adjusted values should be interpreted with caution.

Partial regression coefficients for the regression of systolic blood pressure, diastolic blood pressure, and cholesterol on age while controlling for Quetelet index, and for systolic and diastolic blood pressure on age and cholesterol while controlling for Quetelet index are given in table II for the Ethiopians and in table III for the other Israelis. For the Ethiopians, age and Quetelet index were significantly associated with systolic blood pressure $(p<0.05)$. However, when cholesterol was introduced into the regression equation it showed a significant association with systolic blood pressure $(p<0.05)$ and the association with age and Quetelet index was no longer significant. Diastolic blood pressure was more strongly associated with age than was systolic blood pressure. When cholesterol was introduced into the regression, the significance of the association of age with diastolic blood pressure was not changed. For the other Israelis, Quetelet index was strongly associated with systolic and diastolic blood pressure, age only with diastolic blood pressure, and cholesterol with both systolic and diastolic blood pressure after controlling for
Quetelet index. Cholesterol was correlated with age and Quetelet index. For Ethiopians, neither age nor Quetelet index was associated with cholesterol. The magnitude of the regression coefficients show a larger age related change in diastolic blood pressure for CORDIS.

\section{Discussion}

The results of this study indicate that the prevalence of several major risk factors for coronary heart disease among Ethiopian immigrants, even after they have lived for several years in Israel, is far lower than that observed in Israeli society generally. ${ }^{1011}$ In several other studies a lower prevalence of hypertension has been shown in non-industrialised as compared with industrialised countries. ${ }^{12-14}$ The Ethiopian immigrants to Israel have been shown to have lower blood pressure on arrival, with a subsequent rise after several years, ${ }^{15}$ but in general they were undernourished when first examined.

The usual rise in blood pressure with age observed in Western societies ${ }^{31617}$ was similar in both groups in the present study (although slightly less for the Ethiopian immigrants). In other studies in non-industrialised countries 121318 and among isolated groups such as nuns living in a secluded order, ${ }^{19}$ minimal age related increases have been noted. In fact among some groups of Melanesians both diastolic and systolic blood pressures tend to decline with age among males, whereas among females there is little change in diastolic blood pressure and some increase in systolic blood pressure. ${ }^{12}$ Thus the Ethiopian immigrants to Israel appear fairly
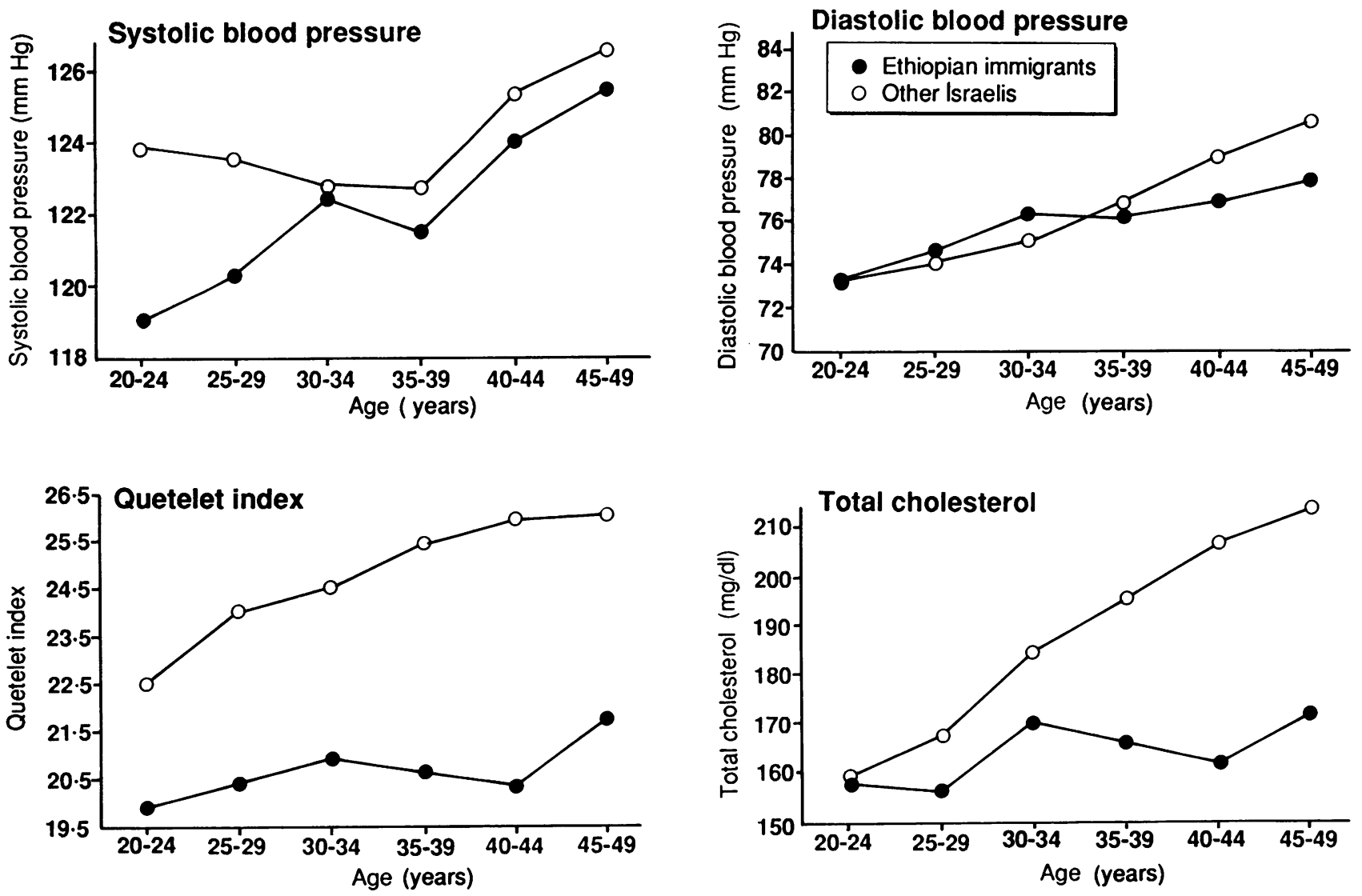

Figure 3 Mean systolic and diastolic blood pressure, Quetelet index, and serum cholesterol by age group for Ethiopian immigrants in Israel compared with other Israelis examined in the CORDIS project. To convert total cholesterol to mmol/litre multiply values by 0.026. 
Table II Partial regression coefficients for blood pressure and serum cholesterol on age and Ouetelet index and for blood pressure on age, Quetelet index, and cholesterol among Ethiopian immigrants

Table III Partial regression coefficients for blood pressure and serum cholesterol on age and Quetelet index, and for blood pressure on age, Quetelet index, and cholesterol among Israelis examined in the CORDIS project rapidly to develop the distribution of blood pressure of the society to which they migrated.

Lipid levels in Ethiopian immigrants on arrival in Israel have been reported as being low. ${ }^{20}$ In the present study, cholesterol levels were evaluated several years after the immigrants had been in Israel. However, unlike the rise in blood pressure with increased length of stay, the serum cholesterol levels observed in the Ethiopian immigrants in the present study remained low at all ages. It appears either that different factors associated with migration affect blood pressure and cholesterol, or that the changes in blood pressure occur much more rapidly than for cholesterol.

\begin{tabular}{lllll}
\hline & \multicolumn{3}{c}{ Independent variables } \\
\cline { 2 - 5 } $\begin{array}{l}\text { Dependent } \\
\text { variable }\end{array}$ & Age & $\begin{array}{c}\text { Quetelet } \\
\text { index }\end{array}$ & Cholesterol $R^{2}$ \\
\hline SBP & $0.165^{\star}$ & $6.795^{\star}$ & - & 0.033 \\
SBP & 0.121 & 5.949 & $0.073^{\star}$ & 0.068 \\
DBP & $0.143 \dagger$ & 3.029 & - & 0.030 \\
DBP & $0.195 \dagger$ & 2.496 & 0.038 & 0.082 \\
Cholesterol & 0.502 & -4.240 & - & 0.019 \\
\hline SBP $=$ systolic blood pressure; DPB $=$ diastolic blood pressure \\
ॠp<0.05, tp<0.01
\end{tabular}

\begin{tabular}{lcclll}
\hline & \multicolumn{5}{c}{ Independent variables } \\
\cline { 2 - 5 } $\begin{array}{l}\text { Dependent } \\
\text { variable }\end{array}$ & Age & $\begin{array}{l}\text { Quetelet } \\
\text { index }\end{array}$ & Cholesterol $R^{2}$ \\
\hline SBP & 0.004 & $11.300 \ddagger$ & - & $0 \cdot 111$ \\
SBP & -0.036 & $11.050 \ddagger$ & $0.018 \dagger$ & 0.113 \\
DBP & $0.220 \ddagger$ & $8.200 \ddagger$ & - & 0.145 \\
DBP & $0.190 \ddagger$ & $8 \cdot 110 \pm$ & $0.013 t$ & 0.143 \\
Cholesterol & $2.060 \ddagger$ & $15.440 \pm$ & - & 0.156 \\
\hline
\end{tabular}

$\mathrm{SBP}=$ systolic blood pressure; $\mathrm{DPB}=$ diastolic blood pressure
$\mathrm{t}<0.01, \neq \mathrm{p}<0.001$
A particularly noteworthy finding was the significant independent association between systolic blood pressure and serum cholesterol among Ethiopians, which was more significant than its association with age or body mass. This finding differs from that observed in populations living in industrialised societies, where age and body mass are invariably much stronger correlates of blood pressure than is serum cholesterol. ${ }^{23}$ The association between cholesterol and blood pressure is not fully understood. Some investigators have proposed that the association between blood pressure and biochemical variables such as serum protein or triglycerides may be due to a reduction in blood volume accompanying increased blood pressure. ${ }^{3}$ In the present study, however, blood pressures among Ethiopian immigrants appeared to have increased whereas serum cholesterol did not, so the association between blood pressure and serum cholesterol is unlikely to be due to changes which may follow a rise in blood pressure. The finding in this study of an independent association between cholesterol and blood pressure, both in a population with a high prevalence of major risk factors for cardiovascular disease and in one virtually free of them, strengthens the possibility that serum cholesterol may, directly or indirectly, be one of the determinants of blood pressure.

The major results of the present study provide evidence of an environmental effect on blood pressure resulting from migration which was not reflected in the serum cholesterol values. This
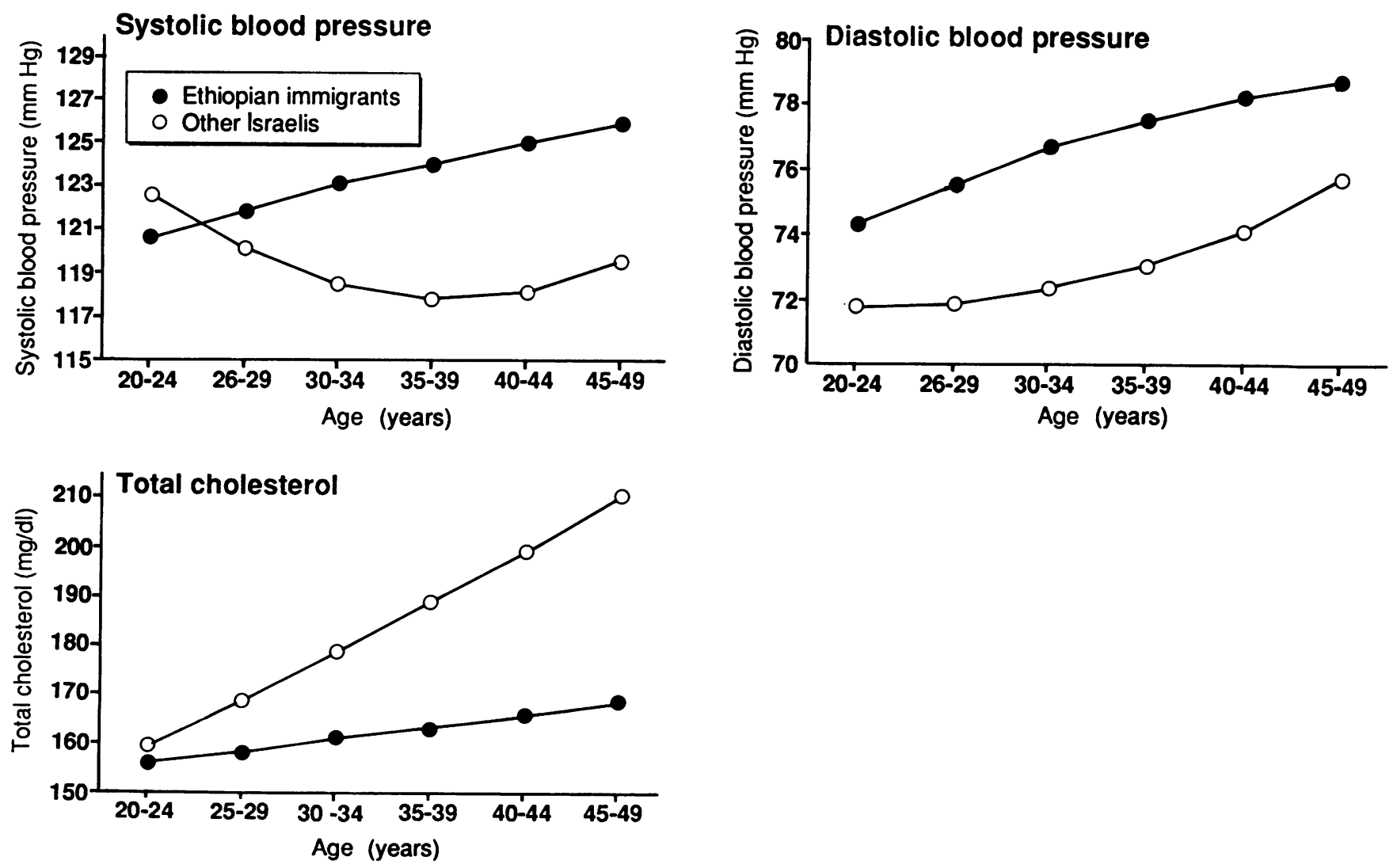

Figure 4 Regression lines of systolic and diastolic blood pressure, and serum cholesterol by age controlling for Quetelet index, for Ethiopian immigrants in Israel compared with other Israelis examined in the CORDIS project. To convert total cholesterol to mmol/litre multiply values by 0.026. 
suggests either that different mechanisms underly these changes or that blood pressure is affected by the process of migration more rapidly than cholesterol.

1 Stamler J, Rhomberg P, Schoenberger JA, et al. Multivariate analysis of the to blood pressure; findings of the Chicago Heart Association detection project in industry, 1967-72. $f$ Chron Dis 1975; 28: $527-48$

2 Green MS, Jucha E. Interrelationships between blood pressure, serum calcium and other biochemical variables. Int $\mathcal{F}$ Epidemiol 1987; 16: 532-6.

3 Havlik RJ, Garrison RJ, Feinleib M, Padgett S, Castelli WP, McNamara PM. Evidence for additional blood pressure correlates in adults 20-56 years old. Circulation 1980; 61: 710-5.

4 Agner E, Morck HI, Brendstrup T, Hollnagel H, Schroll M, Gyntelberg F. Cholesterol, high density lipoprotein cholesterol (HDL) and cholesterol/HDL-ratio versus arterial blood pressure. Acta Med Scand (Suppl) 1981;646: 25-30

5 Khoury P, Morrison JA, Kelly K, Mallies M, Horvitz R, Glueck CJ. Clustering and interrelationships of coronary heart disease risk factors in schoolchildren, ages 6-19. $A m \mathcal{F}$ Epidemiol 1980; 112: 524-38.

6 Marmot MG, Syme SL, Kagan A, et al. Epidemiologic studies of coronary heart disease and stroke in Japanese men living in Japan, Hawaii and California: prevalence of coronary and hypertensive heart disease and associated risk factors. Am ₹ Epidemiol 1975; 102: 514-25.

7 Cruz-Coke R, Etcheverry R, Nagal R. Influence of migration on blood pressure of Easter Islanders. Lancet 1964; i: $697-9$.
8 Salmond CE, Joseph JG, Prior IAM, Stanley DG, Wessen AF. Longitudinal analysis of the relationship between blood pressure and migration: the Tokelau island migran study. Am $\mathcal{F}$ Epidemiol 1985; 122: 291-301.

9 Henderson LO, Saritelli AL, LaGarde E, Herbert PN, Shulman RS. Minimal within-day variation of high density lipoprotein cholesterol and apolipoprotein cholesterol and apolipoprotein A-I levels in normal subjects. $\mathcal{f}$ Lipid Res 1980; 21: 953-5.

10 Kark SL, Gofin J, Abramson JH, et al. Prevalence of selected health characteristics of men. A community health survey in Jerusalem. Israel f Med Sci 1979; 15: 732-41.

11 Green MS, Jucha E, Luz Y. Ethnic differences in the prevalence of selected cardiovascular risk factors in Israel working populations. Israel f Med Sci 1985; 21: 808-16.

12 Maddocks I. Blood pressure in Melanesians. Med $\mathcal{f}$ Aus 1967; 1: 1123-6.

13 Patrick RC, Prior IAM, Smith JC, Smith AH. Relationship between blood pressure and modernity among Ponapeans. Int $\mathcal{F}$ Epidemiol 1983; 12: 36-44.

14 Florey $\mathrm{C} \mathrm{deV}$, Cuadrado RR. Blood pressures in native Cape Verdeans and in Cape Verdean immigrants and their descendants living in New England. Hum Biol 1968; 40 . 189-211.

15 Rosenthal T, Grossman E, Knecht A, Goldbourt U. Blood pressure in Ethiopian immigrants in Israel: comparison pressure in Ethiopian immigrants in Israel: comparison

16 Editorial. Why does blood pressure rise with age? Lance 1981; i: $289-90$.

17 Green MS, Jucha E, Luz Y. Inconsistencies in the correlates of blood pressure and heart rate. $\mathcal{F}$ Chron Dis 1986; 39 261-70.

18 King H, Collins A King LF, et al. Blood pressure in Papua New Guinea: a survey of two highland villages in the Asaro Valley. ₹ Epidemiol Community Health 1985; 39: 215-9.

19 Timio M, Verdecchia P, Ronconi M, Gentili S, Francucci B, Bichisao E. Blood pressure changes over 20 years in nuns in a secluded order. $\mathcal{F}$ Hypertens Suppl 1985; 3: S387-8.

20 Rubenstein A, Landau E, Goldbourt U, Reisen LH. Lipids and lipoproteins in new immigrant Ethiopian Jews in Israel. Am 7 Epidemiol 1988; 128: 153-64. 